\title{
Gender, Sexuality and International Politics in Troubled Times: A Conversation with Laura Sjoberg in Brazil
}

\section{Thais de Bakker Castro*}

Laura Sjoberg is one of the most prolific gender theorists in IR and an almost inescapable reference for those who research international politics through the lenses of gender and sexuality. One of her more celebrated books is Mothers, Monsters, Whores (2007), written with Caron Gentry, in which they discuss stereotypes of femininity in global politics while looking at women who commit violence. She has more recently published 'Trans ${ }^{\star}$ America' (2016), in which she discusses Cynthia Weber's Faking It (1999) and reads aspects of gender and sexuality involved in the USA's foreign policy. She was in Rio de Janeiro for an event held by the International Relations Institute of PUC-Rio, where she composed a panel called 'Rethinking the Borders between Gender and Sexuality' alongside Marysia Zalewski, Elisabeth Prügl and Henry Myrttinen. Her talk was a critique of the dichotomy between war and non-war violence, which proves to be inadequate in many instances, especially regarding sexual forms of violence, which take place identically inside homes and in war scenes, while the former happens more often. The event took place about one week before the second term of presidential elections in Brazil, and later that same day, she was also part of the panel 'The Rise of Conservatisms and the Challenges to the Women, Gender and Sexuality Agendas'.

We talked for about 50 minutes the next day in a semi-structured interview seeking to touch on the topics mobilized in the talks and in her academic work. Many of the questions are situated in the political context in which the event took place (in Brazil, during elections), but also in reference to broader global movements of conservatism: Viktor Orbán had recently banned gender studies in Hungary, and the New York Times had recently published a piece stating that the Trump administration was trying to 'define transgender out of existence' (Green et al 2018). What could be the impact of those moves

Pontifícia Universidade Católica do Rio de Janeiro (PUC-Rio), Rio de Janeiro-RJ, Brazil; thais.bakker@gmail.com. ORCID iD 0000-0001-9958-7566. 
for current global politics? How can we rethink gender and global politics while taking these changes into consideration? Are there ways to resist?

Thais: Thank you for your talk yesterday, by the way, it was great and I have some questions about that and about some of your recent work. I would like to ask you first about 'Trans ${ }^{\star}$ America.' I was just reading it the other day and there is the following passage:

Being queer and trans ${ }^{\star}$ tolerant is part of a new liberalism in the United States. The new US, which I call trans ${ }^{\star}$ America, wields progressive policies on gay marriage, gay military participation, and trans* acceptance as weapons to demonstrate its superiority to the backward states it invades and destroys (Sjoberg 2016: 94-95).

So you say that this is a new 'US identity', and I was thinking that despite the fact that the piece was only published two years ago, there has been some change. Just recently there was news about backlash from the Trump administration regarding trans rights. They are trying to define sex as either male or female in such a way as to deprive trans people of certain civil rights protections. And I was wondering if you believe that this means that we are entering a new 'new United States', or if this scenario may have some impacts on US identity and foreign policy?

Sjoberg: Yeah, I don't really know what to make of that, to be totally honest, because... I was writing about Obama era, USA-Cuba rapprochement, right? Because that piece is a reflexion on the application of 'faking it' to Obama's policy towards Cuba, in the context of the administration's significant pinkwashing. In the Obama Administration, queer rights proliferated quickly, and it was no coincidence that the bestowal of rights started in the military. Military-based pinkwashing painted a comparative advantage for the United States in the 'war on terror' and its other global endeavors, and reflected a new sense of 'self' in US foreign policy. I don't know what to make about the rolling back of both pinkwashing and USA-Cuba rapproachment except that Trump doesn't feel like the USA needs moral superiority to dominate. Several of the administrations before him, Democrat and Republican, really relied heavily on normative language to justify foreign policy. For G. W. Bush it was like, injuring women and children is always and everywhere wrong, and for Clinton it was about human rights. But in the Trump Administration's discourse - such that I've seen, and I tried to ignore it - there's not really a lot of moral superiority language. It's just like: 'I'm better than you and I don't need to justify why', and you get the discourse of domination instead of the discourse of humanitarianism. And it's certainly less pleasant to hear and more aggressive, but at times it has the same policy results. I'm not sure which one I prefer because I think that it's, I don't know... the Trump approach is more honest in some ways.

But I think I care more about the results of the policies in the world. And in a lot of places it's not as different as I wish it was, in that I wish that previous administrations had been better to the world. I don't know if this is an eight-year phase of just being in everybody's 
face, because we certainly had those before - I mean, in a very different way, Ronald Reagan was that - or if it's a change in US national identity or self-perception. I hope it's the former. I have no hope that it is a four-year phase, but I hope it's a phase. But I'm not sure. Because I think almost all of us thought that the radical part of the Republican Party would get to air their temper tantrums during the primaries and then a more modern Republican would have ended up being the president. And then it just didn't happen because both of the last people standing were kind of this crazy right wing, and I actually think Ted Cruz much more than Donald Trump. It was kind of this scary thing, right?

Thais: Yes. And on that note, have you been reading something about the situation here with Jair Bolsonaro?

Sjoberg: A little bit. Not enough to really have a good grasp of it but I can tell people are really afraid.

Thais: Yes. It's very similar to Nazism and Fascism. Some international newspapers are saying he is more like Hitler than Mussolini. I am thinking about the fact that we're seeing many more fascist movements than before, and we don't know if they didn't exist before, or if these people are only just feeling safer to speak out now. Not only that, but also authoritarian governments. I'm thinking about Brazil, of course, but the Philippines as well with Rodrigo Duterte. They're usually very phallic and ultra-masculinized leaders, but despite that... In the case of Brazil, Bolsonaro is very fond of Donald Trump and he says Trump is an example and a person that he intends to get closer to for the good of Brazil and the United States. Of course, Trump is ignoring him completely, but he has a very strong fondness towards him. This makes me think of a certain kind of homoeroticism, in the sense that his masculinity [Bolsonaro's masculinity] is not trying to compete or gain space or face another dominant male, but he's trying to gain their respect somehow. I was thinking if you believe that there's any connection among these simultaneous risings of masculine leaders around the world.

Sjoberg: Well, you know, it is my opinion, at least in the United States, that this was a silent undercurrent for a very long time. It's the politics I grew up around. They just knew they couldn't talk and now they can talk, right? And I think a lot of that has to do in the USA with a sense of the destruction and then reconstruction of white male middle-class masculinity. 'In the good old days I used to be able to support a family and then my wife would do what I told her to do because I brought home the money.' And it's funny because the people that are saying that never lived it, their grandfathers did or something like that, if it was ever really a thing rather than a fantasy. So, I think that there's a little bit of that. I mean, I think watching Trump trying to get elected there was very homoerotic tension with Putin, because Putin sells himself by sex and God knows why that works, but it apparently does. Trump essentially would say 'Oh my God, he's so sexy'. It was just kind of funny to listen to that out of one corner of his mouth and the homophobia out of the other corner. Because I'm like 'Well, if you want that guy...' 
And I don't know, I think that I'd like to think of it in terms of Aaron Belkin's (2012) book about homoeroticism being an undercurrent in the construction of straight, militarized masculinity. He writes about how in the USA military people compete to see how much homoeroticism they can 'endure' and that makes them the bigger man. And it seems to me there's a kind of a little bit of that going on in the Trump administration where like 'I prove I am a man by being able to be in this culture of homoeroticism.' But it's funny because if you look at all these busts of authoritarian leaders there's a homoeroticism to that 'let's just worship the statue of this guy' and it feels like that's just kind of happening in real time now.

Thais: Yes, exactly. It sounds to me a little different from what used to happen between Cuba and the United States or even USSR, a different kind of relationship between these leaders, I'm not sure. It just sounds different somehow.

Sjoberg: Well, in some sense there's no feminized other anymore, which is weird, because that was the how the USA understood Cuba in the 1950s: that's my feminized other. I remember that in the 1990s, when Iraq invaded Kuwait and there was this discourse of invading neighbours at night; it was the feminine state, Kuwait, who had been raped by the masculine state, Iraq. And I don't hear that as much anymore. Instead, I hear some funny language about masculinity, and I don't know what to make of that, because that analogy could be as easily been used in the Russia-Georgia War as it was in Iraq and Kuwait, and in a lot of ways there's more reason to use that analogy there. But it wasn't, I never saw it. Instead it was like: 'We're going to leave that guy to his business so that we can have our business', which is a very different but still a sexual relationship.

Thais: That's true. I guess it's a new scenario. We're not really sure what's going to happen here either. It's the most scary part, because we definitely have some explicit threats to democracy, to minorities and basically to political opposition in general, but we are not sure how strong the institutions are to handle that. And we are also not sure what the relationships between Brazil and other countries are going to be like. We have been reading comments by certain states and organizations saying that they can't hold relationships with an authoritarian Brazil, but at the same time we have Bolsonaro trying to build a relationship with Trump, and Trump is ignoring him completely.

Sjoberg: Uninterested.

Thais: Yes. It's kind of a crazy scenario.

Sjoberg: I was going to say I wonder how he's going to try to attract interest because it's not working right now.

Thais: Exactly.

Sjoberg: And I don't think winning will do it, actually.

Thais: Yeah, I'm not sure it will either. If he hasn't attracted interest yet, and everybody is talking about him, if Trump is not paying attention yet, I don't know what will make him pay attention anymore. 
Sjoberg: Like probably he would have to be able to find it on a map. That was terrible, I'm sorry. I watched this whole speech that Mike Pence made about China, and all throughout the speech he refers to this country called Siri Lanka, like Siri on the iPhone. You've got to be kidding me! I was like 'You couldn't have figured out how to pronounce it before?'

Thais: A little about conservative movements. You've written a lot about women who are on the 'other side of the stereotypes', women who commit violence. Well, these conservative movements are very patriarchal in nature, yet they are finding a lot of adherence amongst women. It's something that they are actually seeking and directing their propaganda towards, at least in Brazil. And many women are actually very into this whole thing, despite the fact that these regimes are threatening very simple rights, like reproductive rights and safeguards against sexual violence. Instead, these movements are offering very bellicose alternatives to enforce order and for me, this obviously shows that there's no 'peaceful nature' in women, but it could also mean many other things. It could say something about political manipulation and heteronormative desires of some kind. I was wondering if you have any thoughts on women's participation in this.

Sjoberg: Individually, women are people who get screwed up. Like men are people who get screwed up. I don't think I've ever been curious why women do stupid things because nobody's ever curious why men do stupid things, right? Or why women do violent things, because men do violent things. I've been interested in why organizations engage in recruiting like that, and different ones of them, I think there are different answers. To me it makes all the strategic sense in the world for a lot of these organizations to recruit and plan women. And for women, for people, like - I think a lot of people get swept up in stuff because they're looking for a place to belong and a place to feel safe, and what feels safe to somebody might be exactly the opposite of what feels safe to me. But I've known a lot of US women who were against reproductive rights and I'm like: 'you have a body', and they were like 'yeah, but I would never want to do anything like that to my body and I would never want anybody else to do it either', and I was like: 'but you have a body'. And I spent a long time trying to argue with very conservative women and I got nowhere except wanting to scream. And I think that it has to do with some sense of purity and control, this association of femininity with chastity, and I think that a lot of women associate femininity with chastity. And that gets you kind of on these big head trips about the state control your reproductive rights and things like that.

I mean, to me these conservatives movements have massive strategic reason to engage and recruit women. Like, mothers tell their sons what to do, and if the liberal answer is 'women are the victims,' then having women speaking is useful. But Al Qaeda, when they started recruiting female suicide bombers, they said: 'it's the end of the world because in no other situation would we think women should get out of their gender roles to do this, so it must be Armageddon Time,' and I think Al Qaeda is probably the last organization I would have guessed would do that, but they managed to do it in a way that didn't compromise their 'gender values.' But it still got them the strategic advantage they were looking for. 
Thais: It's curious, because while they're trying to reject liberal logics, they're also defending some propositions like 'there should be equality of representation' or something like that, and subverting that for their own purposes. For example, in Brazil we elected an extremely conservative councilwoman, she's a law professor and she was elected with a major amount of votes, and conservative parties are using that to do some propaganda by saying that 'leftists, they say that they want women in power but that's a lie because if they wanted women in power, they would be happy that this woman was elected, but they're not happy, so they actually don't want women in power, we want women in power, they want leftist people in power.' For me, it's a very well thought out strategy and it's startling, because it's hard to discuss with.

Sjoberg: There's no great answer to that, because in theory, if you do support women being in power, then it would be holding them to a higher standard to care about their politics. Like: 'I want women in power and I want femininity in power and I don't care if they come in the same body or not', but at the same time there's no newspaper in the world that's going to report that in a useful way. It was interesting to me, because we'd been having a little bit of that when Sarah Palin was running for vice-president of the United States and everybody was like: 'look, it's a woman on a ticket that might win for the first time ever', and the Democratic party had just voted down a woman to be their candidate, and there was a lot of people saying: 'if you really care about women in the executive office, here's one.' And there were arguments against that, but it was a much harder argument than I wish it had been.

Thais: Also thinking about Zalewski's comments yesterday, I believe they allow for us to think about the need to rethink our goals and what we mean by gender, by women, and how can we speak of gender in a world that's censoring us? We cannot speak of gender anymore, it has a very heavy load of rejection, at least here, in Brazil. They're trying to basically banish the word from schools through legislative bills. They have very carefully thought this out, Bolsonaro has expressed multiple times that he wants to implement distance education at all levels in order to avoid 'gender ideology' and 'communist indoctrination.' So, we see that they have strategies for recruiting women and we see that they are taking some liberal premises and turning them around while at the same time it's making it really hard for us to speak of gender and to think about who are the women we are talking about. In that sense, [Marysia Zalewski's] comments yesterday seemed to be related to your work, since you are interested in these women that are not the essential 'Woman' of our imagination. Do you have any thoughts on how we may rethink gender and 'womanhood' in this scenario?

Sjoberg: I really do think separating it from political agendas advocating femininity is a thing. So, to me, I want to talk about antimilitarism and about care and about ending sexual violence, and I want to talk about women in office, and I don't think I get anywhere by talking about them at the same time. The percentage of women in public office doesn't correlate with any other indicator of gender equality in the world. Some people think that means that putting women in public office should be less of a priority. I think it should 
be a priority, but for completely different reasons. Rather than expect women to measure up to some particular notion of femininity, I want to say: 'women in government have no obligation to be feminine.' But, on the other hand, my government owes me caring about values associated with femininity. An American female political candidate who cried on the campaign trail was treated like some sort of national emergency: do you want somebody emotional with their finger on the nuke button? (For what it is worth, there is no button!) My first reaction was to defend that she was not emotional, but just having a bad day. And then I thought this was actually me valuing values associated with masculinity in a political context, because in theory, if some president dude actually needed to nuke somebody, of course you want them to feel it. Right? You'd probably want them to be able to do it, but you wouldn't want them to be like: oh, whatever, I'm going to kill 150 million people. You actually want them to feel empathy and guilt and fear and the seriousness of it. I think if you weren't feeling it when and if you had to do that, then I don't know what kind of monster you would actually be. And it took me several hours to realize that I didn't even mean my first reaction. So, I think we get so wrapped privileging the values associated with masculinity in politics, and sometimes we don't even know we were doing it, and so it seems to me that when you're watching someone say: 'I'm going to take over how young brains are formed,' my third thought is: 'How afraid are you of people thinking for themselves?' Because that's the real problem. Let's pretend that this dude's right and the public school system teaches people communism and gender ideology - which seems unlikely -, you really have to fear people thinking to have a problem with it. Fear argument and discourse and difference, because in theory if somebody taught all of my students something that was absurd, at this point, I would like to trust them to be like: 'that's absurd, because I'm not teaching them facts, I'm teaching them critical thinking skills. I would like them to be able to process and ask questions without me having to ask them, and it seems to me that that's the real question: 'why do you just suppress public political discourse?' I don't think you can convince those people that education isn't political discourse. Because they just have it in their dogma that it is. If you're right and your worldview is fine and sane then it doesn't do you any harm for people to talk about it.

Thais: The first part of your discussion about the president feeling things really reminded me of Carol Cohn's (1987) paper, that I find extremely fascinating, and I'm thinking that maybe not much has changed since then in terms of the dominant rhetoric of high politics or something.

Sjoberg: Well, not a lot, and also my ridiculous self of course read that previous to replicating the same mistake, right? I read it. I understood it. I agreed with it and, in that moment, it didn't go together in my head. And it took me several hours of waiting, 'What's my problem here?' I don't know.

Thais: It's not the same specific scenario [described in Carol Cohn's (1987) paper] as in Brazil, because we don't have nuclear weapons. In our history there are not many - well, there are - many wars, but they're kind of hidden. We don't think of ourselves as if we participated in wars. It's not really a part of our 'national identity', let's say, and this is actually 
a lie. We are in war all the time and we are in war with ourselves, most of all, which is why I thought that your comments yesterday were very relevant, when you criticized that dichotomy between war violence and non-war violence... what even is that dichotomy? I could safely say that Brazil experiences 'war violences' all the time. We have all the kinds of 'war violences' that you can think of, from torture to executions to political persecutions, and we have every single one of them but the classification [of 'war violence'] doesn't seem to apply, and many people here in IRI are working on that kind of space of discussion. I think it's very particular to post-colonial contexts. But what I want to ask in regard to your talk yesterday is what you think about the State's role in perpetrating and allowing for both of these types of violence [war and non-war] to happen in a kind of continuum, which they are. I was actually reminded of Foucault's inversion of Clausewitz's proposition, that politics is the continuation of war through other means. That's why I wanted to ask you to speak a little more about the State's role in this.

Sjoberg: I think different states have different roles in different times. Right? So, some states facilitate that sort of... significant amounts of violence, because they can't control their own territory, and some states facilitate violence because they are controlling their own territory, right? And some states... it comes in very different forms. Certainly, the US State does a lot of violence to a lot of people, but in a less direct way than places where there's direct political conflict, civil war. We imprison people on the basis of race all the time, some feminist scholars call it the prison industrial complex, which seems to me to be pretty accurate, and that's completely different than a state in which there's an active civil war, but it doesn't make it not violent. So, I think, I don't have a good [definition of] 'this is what states do,' but rarely have I seen a large-scale political or politicized violence that states don't have some sort of responsibility for, either through their inability or lack of interest to control it or through their active perpetration of it.

Thais: Still on yesterday's talks, many of us were very disturbed by the video that Zalewski ${ }^{2}$ showed. I think it has stuck with us because we're all really scared. We were thinking that it might be us tomorrow, being persecuted by the military - because the threat is a military dictatorship -, we were impacted by that, but on the other hand, I thought that the video had a very strong connotation about the politics of empathy, in a sort of way, because they were inverting a situation that actually happens. They were putting white people in the place of [something that usually happens to] black people to provoke an empathetic reaction, to provoke some other response less indifferent in people and I was wondering if you had some thoughts on empathetic responses to these war and non-war violences.

Sjoberg: So, one of the messages that videos sent me was this still overwhelming association of whiteness and purity, and maybe it's trying to play on white people's empathy that way but it seemed to also be communicating that the white blond people are pure, with their nice middle-class house. And I think that one of the hardest parts is that a lot of the time - and I am not excluding myself from this - it kind of is still at a place where you distinguish 'Us' from 'Them,' like, where you are the pure and you're having an empathetic reaction to the terrible impurities that happened to somebody. I'm not sure how 
productive that is. I think there's some utility in feeling it. There's some utility in not reading it, like in a history book where you don't feel anything. But, like, if you feel the tragedy, but not the complexity that also seems to have some problems, and there have been people who have been writing about this over the last decade. Victimhood is itself a very dangerous weapon, which essentially constitutes a different sort of purity and justifies somewhat carte blanche behaviour. So empathy is really important to me and I really feel like when you spend a lot of time trying to feel and feel one's way to knowing a lot of these terrible things that go on, I also feel like...at the point where I'm saying I empathize, I think that's not complicated enough, because when you're talking about the fear that things like that that may happen on a wide scale, I can't, I can't identify with that. I can think about what it would be like to identify with that maybe, but I can't actually feel that, and I think I need to be very careful and I claim to try, because it does get very different when it's personalized. So, to me, it's an important part of the response, but I think the other important part of the response is realizing that you aren't and can't be the other with whom you're trying to empathize.

Thais: I was thinking about empathy, after the presentations yesterday, because it seems to me that many states are taking steps back from international regulations, which are the places in which you can see more clearly this division between what is 'war violence' and 'non-war violence,' what is permitted or tolerated and what's absolutely not allowed. Of course, we know that it's not usually how it goes, it's all pretty theoretical, but it says something about how we frame things in our minds, our imaginaries of war, and I guess we used to believe sometime in the past that the world would walk in a kind of linear path towards making regulations stick more, but we're now seeing that we're taking steps back. So I think we're all at a place to wonder what resistance can be like, what are other paths to conceptualize a better... I don't know, international environment, let's say, better politics, more well-being for people. That's not merely about law, because... the feeling that we have is that we're taking major steps back, still in that metaphor of a linear timeline, we're not going forwards anymore. And I think it says something about conceptualizing time in a different way, and maybe thinking about politics in a different way. And empathy just occurred to me as a key to think resistance because of yesterday's talks. But I was thinking if you also had some thoughts on how to improve our conceptualizing of violence, if we can somehow be more alert to violence that is being normalized, but not in a way as to pursue the broadening of legal definitions, but some other path.

Sjoberg: You're much more of an optimist that I am. A lot of the answers to these questions are 'I don't actually know if it's possible', and I wouldn't be writing about it if I had given up, but on the other hand I don't think I have as great a sense of what the potential solutions and might be. To me, I like the research work on everyday terrorism and intimate warfare. I think that's getting some play like. People are reading a little bit of that stuff outside of academia and I think that might matter. I honestly think that it matters to juxtapose it as a security issue, but the problem is that the people who are selling that in the international arena today are selling it in an instrumental way. They're saying 'because women are better for peace, then you gotta quit abusing women', instead of 'it might be 
a good idea to quit abusing your women,' regardless of the relationship between gender equality and peace. The problem with that is that it gives you license to do whatever you'd like to women's bodies to stop war, which this week might be involving them in politics and, next week, it may be something significantly more sinister. So, to me, a non-instrumental advocacy for just a very basic right to exist without terrible violence seems to be a decent way to go. But there are so many angry people and movements in the world that I'm not sure how that goes, because you know, it's not like people use this stuff so instrumentally, they twist it around and make it backwards and make it suck more. I watch this same instrumentalization happen over and over again and I worry about that.

Thais: I have one last question. In this context of new masculinities and new power plays, do you believe that there's a new... that there has been a change in the dominant stereotypes of women? Well, I'm thinking about your past work about the stereotypes of women in the Iraq war (Sjoberg and Gentry 2007), like what you just said, about Bush invading Iraq to save the women, and at the same time we had Lynndie England, representing another stereotype, of villain. So, they [these women] work as kind of very broad stereotypes to mobilize military politics. I was wondering if you think that in this context, of new kinds of masculinities that may be a little more aggressive - or, not aggressive, but like you said, they are feeling less obligated to justify themselves - do you think there has been a shift in some kind of dominating stereotypes in the military context?

Sjoberg: In the United States certainly, but if you think about it, like the hyper-masculine 'I can do whatever I want' thing, like Saddam Hussein's answer to G. H. W. Bush in 1990s. G. H. W. Bush is like 'real men don't invade their neighbours at night' and Saddam Hussein is like, something to the effect of 'come over here and I'll show you what a real man is.' Ten years later, discourses were completely different. Dominant definitions of masculinity really do vary a lot in time and space and place. The only thing that doesn't vary is that they exist. But they are unrecognizable sometimes from one context to another. And I think that's a lot of what's happening, nobody disagrees that states should be 'real men.' The question is just like what a real man is to my state right now and I think it's definitely different in the USA now than it was 15 years ago, when I was writing about [Lynndie] England. Much different but maybe we'll have this conversation again 8 years from now, and it will be much different again.

Thais: Yeah, it's just clearer in retrospect. It sounds almost as if it were clear back then, which I'm sure it wasn't... we always need to look with a certain distance to understand, but we still read a lot of that work (Sjoberg and Gentry 2007) with undergrads and in our classes, so I was just wondering if you had some new ideas about some new movements.

Sjoberg: For some reason or another in the United States we took a break from being crazy homophobic in the executive branch and it wasn't that it didn't exist a little bit in the culture, but in ways that for some reason or another just wasn't something we were worried about. And then Trump is crazy homophobic, not necessarily internationally although that - but also in the very personal sense, where he has to prove his straightness constantly and I think that it shows, you know, in how he talks about women, but I also 
think it shows in how he talks about other States. My sense is that this sense of hyper-masculinity is externalized because the mirror is too scary for him.

Thais: Well, I guess that's it. Thank you very much for your time and availability and I am very happy to have talked to you.

\section{Notes}

1 'Trans* America' is the title of an article by Laura Sjoberg (2016).

2 In her talk the day before, Marysia Zalewski showed a short video depicting explicit scenes of torture and sexual abuse committed by military men against a white family. Those are events that supposedly happened in Congo.

\section{References}

Belkin, A. 2012. Bring Me Men: Military Masculinity and the Benign Façade of American Empire 1898-2001. New York: Oxford University Press.

Cohn, C. 1987. 'Sex and Death in the Rational World of Defense Intellectuals.' Signs 12 (4): 687-718.

Green, E L, K Benner and R Pear. 2018. “Transgender' Could Be Defined Out of Existence Under Trump Administration. The New York Times, 21 October. At https://www.nytimes.com/2018/10/21/ us/politics/transgender-trump-administration-sex-definition.html [Accessed 16 November 2018].

Sjoberg, L. 2013. Gendering Global Conflict: Toward a Feminist Theory of War. New York: Columbia University Press. . 2016. 'Trans ${ }^{\star}$ America.' Millennium: Journal of International Studies 45 (1): 91-97.

Sjoberg, L and C E Gentry. 2007. Mothers, Monsters, Whores: Women's Violence in Global Politics. New York: Zed Books.

\section{About the Author}

Thais de Bakker Castro is a PhD Candidate at the International Relations Institute of the Pontifical Catholic University of Rio de Janeiro (IRI-PUC-Rio). She has a Master's Degree from the same institution, in which she researched gendered readings of freedom found in narratives about the Kurdish YPJ (Women's Protection Units), and a Master's Degree in Philosophy from the Federal University of Rio de Janeiro (PPGF-UFRJ), in which she researched possible theoretical understandings of the nation-state through Judith Butler's philosophy. She is currently conducting an interdisciplinary research project on political visualizations of global futures, combining themes such as political myths, metaphors, imagination and imaginaries.

Received on 19 November 2018, and approved for publication on 22 November 2018.

\section{(cc) BY-NC} https://creativecommons.org/licenses/by-nc/4.0/ 
